\title{
Assessment of Human-Tiger Conflict and Its Community Based Mitigation Efforts in Madi Valley of Chitwan District, Nepal
}

\author{
Sita Dahal ${ }^{1}$, Dol Raj Thanet ${ }^{2 *}$, Deepak Gautam ${ }^{1,3}$ \\ ${ }^{\prime}$ Tribhuvan University, Institute of Forestry, Pokhara Campus, Nepal \\ ${ }^{2}$ Tribhuvan University, Institute of Forestry, Hetauda Campus, Nepal \\ ${ }^{3}$ Beijing Forestry University, School of Forestry, \\ School of Ecology and Nature conservation, Beijing 100083, China \\ * Corresponding author: dolrajthanet@gmail.com, ORCID: https://orcid.org/0000-0002-3202-1581
}

\begin{abstract}
Human fatalities and livestock depredation are the ultimate manifestation of human-tiger conflict (HTC). It is one of the major challenging issues that need to be sorted out where such incidences occur frequently. This study aimed to investigate the status of HTC and mitigation measures adopted by local communities in Madi valley adjacent of Chitwan National Park (CNP). Data were collected through household interviews $(\mathrm{n}=52$, including $25 \%$ victim's households), direct field observation and CNP archive records from 2014 to 2018. This study revealed that average livestock depredation was $15.60(\mathrm{n}=78$, mean=5.06, $\mathrm{SE} \pm 1.66)$ animals per year and among them goats were highly depredated animals $(n=39$, mean=7.80, SE \pm 2.33 ). It also showed that livestock depredation trend increased at the rate of 4.1 animals per year but that of human casualties decreased at the rate of -0.3 persons per year during 2014 to 2018. Predation proof corrals, mesh wire fencing, traditional fencing using white cloths and livelihood diversifications were the major local mitigation efforts adopted by local people. However, detailed studies on effectiveness of locally adopted mitigation techniques along with further investment to implement them from government line agencies and conservation partners are suggested for strengthening human-tiger co-existence in the study area.
\end{abstract}

Keywords: Human casualties, livestock depredation, co-existence, conservation, mitigation

\section{Introduction}

Human-Wildlife Conflict (HWC) is a widespread manifestation throughout the world and has become a major problem for many centuries (Wang and Macdonald, 2006; FAO, 2009). The most common forms of HWC are loss of livestock, human casualties, crop raiding and property damage (Gurung et al., 2008; Ogra and Badola, 2008; Inskip and Zimermann, 2009; Silwal et al., 2017; Lamichhane et al., 2018; Joshi et al., 2020). Conflicts are particularly severe in the regions where large predators occur (Polisar et al., 2003; Wang and Macdonald, 2006; Lamichhane et al., 2017), and where the resource use by local people and wildlife overlaps (Karanth and Kudalker, 2017). Large carnivores are the most conspicuous species of HWC and are usually considered as a risk to human safety and livestock depredation.

Among the large felids, especially tigers are predominantly disposed to conflicts with human beings due to their large home range and dietary necessities (Inskip and Zimmermann, 2009). 
Historically, man-eating by tigers was low in places where there was an ample supply of natural prey and widespread habitat into which human encroachment was only gradual (Tilson and Nyhus, 2010). The common forms of humantiger conflict (HTC) are tiger attacks on humans and their livestock and threats to human safety in the vicinity of human settlements (Goodrich, 2010). However, there were increased cases of livestock predation by tigers in many places due to poor livestock husbandry and management practices (Mishra et al., 2003). Possible causes of livestock depredation by tigers are often related to guarding and herding practices, grazing pastures, and poor quality of corrals to keep livestock at night (Jackson, 1999; Wang and Macdonald, 2006). In many parts of the Asian region, such incidences are likely to be higher where livestock are unrestricted to roam without close supervision (Tilson and Nyhus, 2010).

In many places on the Indian subcontinent and parts of South East Asia, tiger attacks on human beings exerted a substantial toll a century ago (McDougal, 1987). Since then, tiger population and the forests in which they once colonized have decreased at alarming rates (Dinerstein et al., 2007). This has decreased the human fatality cases, and the places where tiger attacks happen (McDougal, 1987; Sanderson et al., 2006). Conversely, human-killing is still a problem in Chitwan National Park (CNP), where the rate of humankilling has been augmented six folds from an average yearly death of 1.2 (1979 - 1998) to 7.2 person per year from 1998-2006 (Gurung et al., 2008). In between 2007 and 2014, an average of 4 persons were killed and 2.7 persons injured, and similarly an average of 44 livestock were killed per year(Dhungana et al., 2017). Within the buffer zone of CNP, the highest number of human killing was recorded from Ayodhyapuri buffer zone user committee in Madi valley (Lamichhane et al., 2018). In recent years, increased tiger population (Karki et al., 2015; DNPWC and DFSC, 2018) with reduced poaching and forest restoration in community forests in buffer zones has increased the probability for HTC (Wegge et al., 2016; Chanchani et al., 2014; Gurung et al., 2008). The high-quality tiger habitat in CNP serves as a source for tigers dispersing into more marginal habitat adjacent to human settlements (Smith, 1993). Besides, CNP harbours other mega animals (rhinoceros, elephants, etc) that commonly attack human beings (GON, 2013). Similarly, Chitwan district population has been increasing due to high immigration and birth rates (Gurung et al., 2008) after the eradication of Malariya in 1950s. Increased risks of attacks on humans and livestock depredation by tigers led to a negative attitude toward tigers (Goodrich, 2010) and such incidences also reduce support from local people in tiger conservation (Löe and Röskaft, 2004; Karanth and Gopal, 2005; Carter et al., 2013).

There are several factors like behaviour 
of tigers, distance of park boundary, livestock holdings and community response are crucial to determine the level of conflicts in a particular location (Van Bommel et al., 2007). However, previous studies on HTC have mainly focused on spatial and temporal patterns of human casualties, livestock loss and retaliation killings in CNP (Nyhus and Tilson, 2004; Muhammed et al., 2007; Gurung et al., 2008; Bhattarai and Fischer, 2014; Silwal et al., 2017; Dhungana et al., 2017), and recommended enhancing the management practices in and around the protected areas. For effective conservation of large carnivores like tigers, the greatest challenge is to minimize the conflicts with human beings. It is difficult to eradicate the risk of tiger attacks completely; however, it can be reduced to an endurable level so that local communities can accept it. The fourth amendment of Nepal's National Parks and Wildlife Conservation Act 1973 made in 1993 aims to address some of those issues by making provision of integrated community - based conservation and development approach to enhance the level of tolerance among local people (GON, 1973). Similarly, the second amendment of Wildlife Damage Relief Guideline 2013 also aims to increase the level of tolerance of wildlife damage with some additional provisions so that people and wildlife can co-exist (GON, 2013). In contrast, local people claim that BZUCs spend more funds in community development activities than on conflict mitigation measures (Silwal et al., 2013). In many locations local communities are compelled to implement some locally available mitigation measures such as electric and mess wire fences, predation proof enclosures to escape from tiger attacks (Lamichhane et al., 2018). There have been limited studies on trends of tiger attacks and its mitigation strategies adopted by local communities in CNP and Madi valley in particular. Therefore, we investigated both the incidence of HTC and its communitybased mitigation efforts in greater depth as effective conflict mitigation measures require comprehensive information on the underlying causes contributing to those conflicts (Thorn et al., 2012). There is an utmost need to develop a proper database on conflict incidences and processes to respond to those conflicts immediately when they occur. Without a better understanding of HTC and a concerted effort to address the problem proactively, future landscapelevel tiger conservation efforts may be jeopardized (Nyhus and Tilson, 2004). This study could substantially support tiger conservation initiatives by documenting the existing conflict mitigation practices adopted by local communities residing in the vicinity of tiger habitation.

\section{Materials and Methods}

\section{Study Area}

Chitwan National Park (CNP), located in south central Nepal, was established in 1973 as Nepal's first national park covering an area of $952.63 \mathrm{~km}^{2}$ in the subtropical lowlands of the inner Terai. 
CNP was enlisted as an UNESCO's world heritage site in 1984 for its unique ecosystems of international significance (Majupuria and Majupuria, 1998). Madi valley (including Madi Municipality) lies in the buffer zone of CNP extending over $218.52 \mathrm{~km}^{2}$ (Fig. 1). There were four buffer zone user committees (BZUCs), namely Panchpandav, Rewa, Bagauda and Ayodhyapuri; and 10 buffer zone community forests user groups. These buffer zone (BZ) forests link CNP to Parsa National Park in the east and the Valmiki Tiger Reserve (India) in the south, and these three protected areas support to one of the largest tiger populations in South Asia (Wikramanayake et al., 1998; Dinerstein et al., 2006; Ranganathan et al., 2008). At about 77\% area of Madi valley is functional wildlife habitat, which includes grasslands, shrub land, forests, river and water bodies, and the rest (33\%) includes agriculture land and settlements (MM, 2017). Madi valley is home to more than 43,402 people comprising of mainly Bramhan/Kshetri and Tharu followed by other ethnic groups (MM, 2017). Livelihoods of local people are predominantly based on subsistence farming system including agriculture, livestock and fish farming, and this is similar across most ethnic groups (Sharma, 1991; Budhathoki, 2012). As a result, local communities and tigers have to share limited resources, leading to several cases of HTC in the buffer zone of CNP including Madi valley (Gurung et al., 2008; Dhungana et al., 2017; CNP, 2019).

\section{Data Collection and Analysis}

We collected data (incidents of human casualties and livestock depredation) from the archives kept by CNP office, mainly recorded in applications for relief fund (Gubbi, 2012; Silwal et al.,

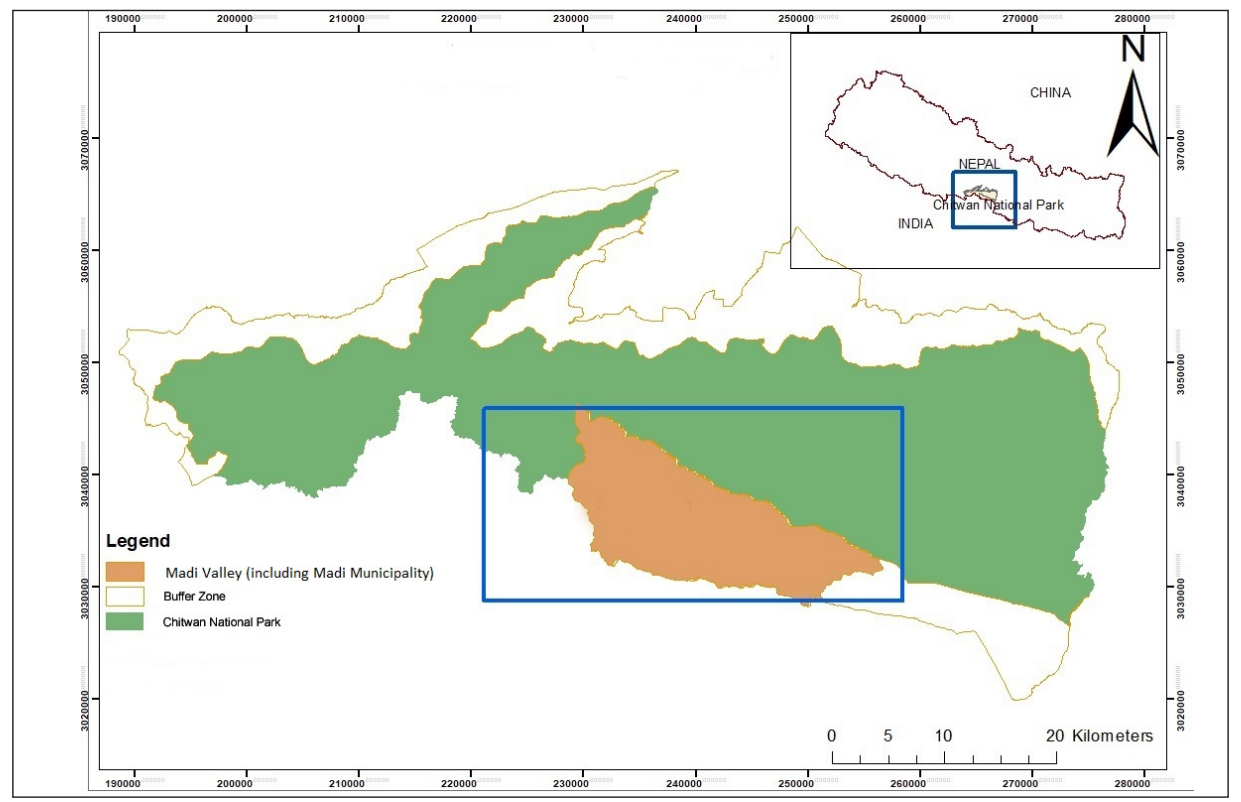

Figure 1: Location map of study area showing Madi valley of Chitwan district, Nepal 
2017) of wildlife victims caused by tigers, for fiscal year 2014/15-2018/19. The data of tiger attacks on humans included types of damage (kills or injuries), location and date (park or buffer zone), whereas the livestock loss data included type of livestock (goats, buffalo, cow/ox or pigs), location and date (village, BZUC and ward number of Madi Municipality). Wildlife victims of the buffer zone report the conflict incidents through formal applications to the local authorities (BZUC or park) mainly to claim relief fund. Local authorities (especially representatives from local government, BZUC, police, etc) verify the conflict incidents and consequently release relief as per Wildlife Damage Relief Guideline 2013 (GON, 2013). We cross-checked the park archival data set of livestock depredation and human casualties by triangulating them through household questionnaire surveys $(\mathrm{n}=52)$ with victims or their family members, and other neighboring people and got supplementary information about those incidents. In our survey, we interviewed about $25 \%$ of the total victim households including both those suffering attacks of tigers on humans and those suffering livestock depredation $(n=20)$ purposively and in addition to that at least one neighboring household $(n=32)$ was selected randomly representing each BZUC in Madi valley to reduce the biasness (Table 1). We used a semi-structured questionnaire survey (Punch, 2006) to obtain information on perceived HTC as well as the mitigation measures adopted by local communities to minimize the conflicts. The household surveys were conducted in Nepalese language with consent of all respondents during the month of February and March 2018. Data were analyzed using descriptive statistics such as mean, frequencies in MS Excel to analyze the pattern of human casualties and livestock loss during fiscal year 2014/15 to 2018/19. Further, the research team observed the conflict prone sites and meanwhile recorded the mitigation measures adopted by local people in the study area.

Table 1: Sampled households (HHs) during household interviews

\begin{tabular}{|c|c|c|c|}
\hline \multirow[b]{2}{*}{$\begin{array}{l}\text { Buffer Zone } \\
\text { UserCommittee } \\
\text { (BZUC) Name }\end{array}$} & \multirow[b]{2}{*}{$\begin{array}{c}\text { Total } \\
\text { victim } \\
\text { HHs }\end{array}$} & \multicolumn{2}{|c|}{ Sampled HHs } \\
\hline & & $\begin{array}{l}\text { Victim } \\
\text { HHs }\end{array}$ & $\begin{array}{l}\text { Non- } \\
\text { victim } \\
\text { HHs }\end{array}$ \\
\hline Panchpandav & 18 & 5 & 7 \\
\hline Rewa & 15 & 4 & 7 \\
\hline Bagauda & 1 & 1 & 3 \\
\hline Ayodhyapuri & 39 & 10 & 15 \\
\hline Total & $73 *$ & $20 * *$ & 32 \\
\hline
\end{tabular}

* CNP records; HHs affected by tigers (livestock lost and human casualties) since the last five years (2014 to 2018)

**25\% of the total victim HHs

\section{Results}

The average livestock holding of the sampled households was 7.72 animal per household and among them goat rearing (mean=3.20) was frequent in the study area (Fig. 2). During the fiscal year 
$2014 / 15$ to $2018 / 19$, there were 3 human casualties and 3 injuries followed by 78 incidents of livestock depredation in 73 households resulting from tiger attacks (Table 2). The average human victims were 1.20 persons (injured, mean $=0.60$, SE and killed, mean $=0.60$, SE per annum, whereas the average livestock depredation was 15.60 animals $(n=78$, mean=5.06, SE \pm 1.66 ) per annum. So, our study revealed that the trend of livestock depredation has increased at the rate of 4.1 animals per year but that of human casualties has decreased at the rate of -0.3 persons per year (Fig. 3). Among livestock loss incidents, goats were highly depredated animals $(n=39$, mean $=7.80$, SE followed by buffalo $(n=17$, mean $=3.40, \mathrm{SE}$ and cow/ox ( $n=20$, mean 4.00, SE ). Among them, about half $(50 \%)$ of the livestock killings were of goats, followed by cow (26\%) and buffalo (22\%). The conflict incidents occurred most frequently $(53.42 \%)$ in Ayodhyapuri BZUC followed by Panchpandav, Rewa and
Bagauda BZUCs respectively (Table 1). In contrast, there were no cases of tiger retaliation due to HTC in the study area within the selected time frame. Most of the human casualties were recorded at the fringe of buffer zone forests and national park. Majority of depredation incidents (48\%) were of the livestock grazing in the fringes of buffer zone forests followed by livestock in the sheds at night $(33.33 \%)$ and livestock grazing in fallow agricultural land $(19.04 \%)$.

Our study revealed that only about $17 \%$ of total respondents applied preventive and mitigation measures such as mesh wire fencing, predation proof enclosures and traditional fence with white cloths to minimize livestock loss due to tiger attacks. Among them, predation proof enclosures followed by traditional fence with white cloths were commonly practiced mitigation techniques. During field visits, we observed that CNP through BZUC has implemented some

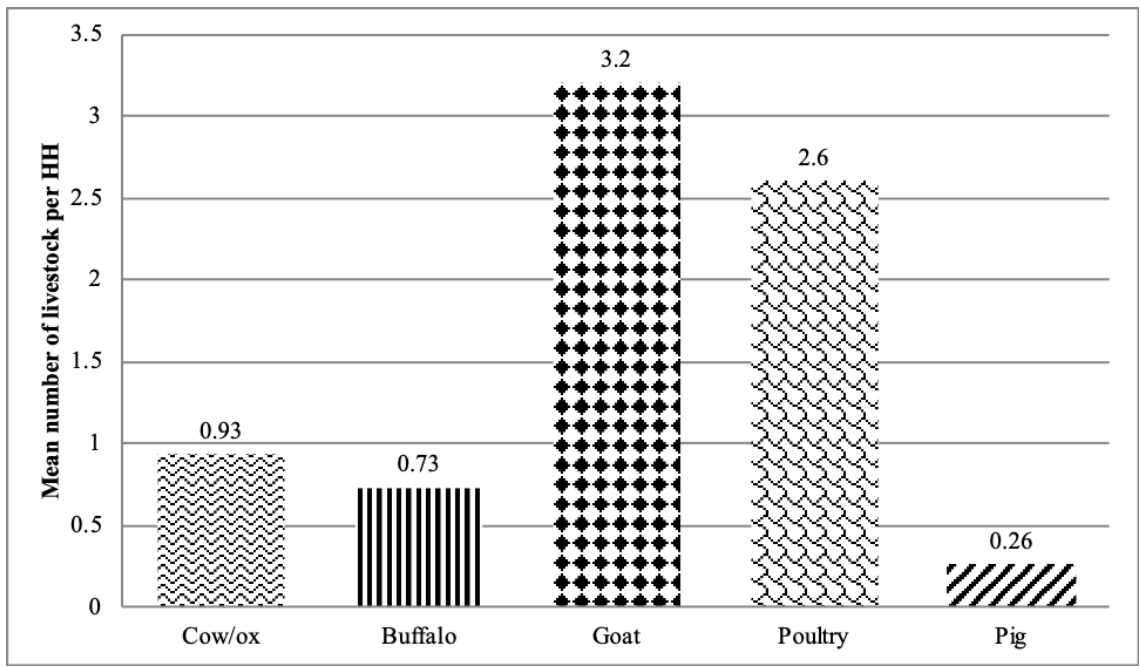

Figure 2: Livestock holding status in Madi valley of Chitwan district, Nepal 
mitigation measures such as solar fencing, mesh wire fencing, support for fish farming and skill development program (tailoring program for women, house-wiring, plumbing) as means of livelihood diversification.
CNP by Gurung et al., 2008 (7.2 human deaths per annum, during 1998-2006) and Dhungana et al., 2017 (4 human deaths per annum, during 2007-2014). This reveals that the rate of human fatalities has been decreasing (-0.3

Table 2: Human-tiger conflict incident records in Madi valley during fiscal year 2014/15 to 2018/19.

\begin{tabular}{|c|c|c|c|c|c|c|c|}
\hline \multirow{2}{*}{ Fiscal Year } & \multicolumn{3}{|c|}{ Human Casualties } & \multicolumn{4}{c|}{ Livestock depredation } \\
\cline { 2 - 8 } & Injured & Killed & Total & Goat & Buffalo & Cow & Total \\
\hline $2014 / 15$ & 1 & 2 & 3 & 4 & 1 & 2 & 7 \\
\hline $2015 / 16$ & 0 & 0 & 0 & 6 & 5 & 0 & 11 \\
\hline $2016 / 17$ & 1 & 0 & 1 & 6 & 1 & 6 & 13 \\
\hline $2017 / 18$ & 1 & 0 & 1 & 17 & 2 & 5 & 24 \\
\hline $2018 / 19$ & 0 & 1 & 1 & 6 & 8 & 7 & 21 \\
\hline Total & 3 & 3 & 6 & 39 & 17 & 20 & 78 \\
\hline
\end{tabular}

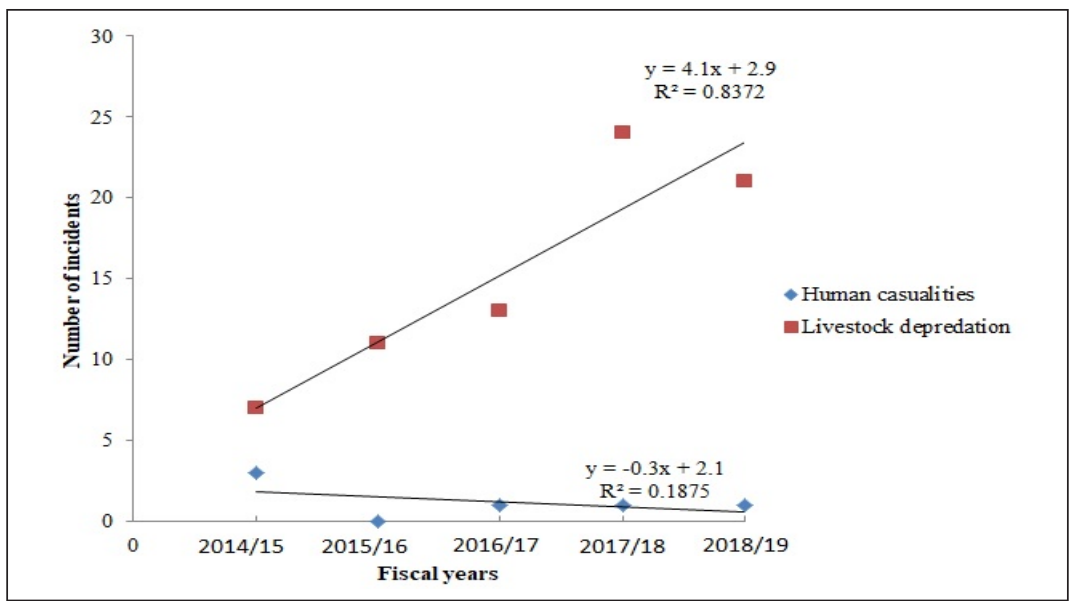

Figure 3: Trends of human casualties and livestock depredation in Madi valley of Chitwan district, Nepal.

\section{Discussion}

We relied primarily on conflict incident records of CNP and BZUC followed by household surveys for the validation of wildlife damage cases (Dhungana et al., 2017). This study shows lower incidence of human casualties by tigers in the study area (killed $=0.60$ persons per year, injured $=0.60$ persons per year, during fiscal year 2014/152018/19) than the study conducted in persons per year), and it could be for the reason that our study is concentrated only in the Madi valley, southern buffer zone of CNP. In spite of increasing tiger population in the park (Karki et al., 2015; DNPWC and DFSC, 2018) and human population in the buffer zone, no increase on human fatalities or injuries from tiger were recorded during the study period. This could be attributed to less human-tiger interaction as an impact of installation of solar and mesh 
wire fence along the forest border in the buffer zone to separate forests and farmlands/settlements through buffer zone management programs, reduction of dependency on forests and livelihood diversifications. Our results revealed that the annual average loss of livestock were 15.60 animals with an increasing trend of 4.2 animals per year, which is lower than what was found in the study conducted by Dhungana et al., (2017) in and around CNP including Mady valley between 2007 and 2014 (an average of 44 livestock killed per annum). The highest number of livestock depredation occurred in the areas of Ayodhyapuri BZUC of Mady valley, which is consistent with the study conducted by Gurung et al., (2008) in CNP. It could be for the reason that Ayodhyapuri BZUC has the longest adjoining boundary with the national park. Our study found that goats were most frequently depredated animal $(50 \%)$ in the study area, which is similar to the finding of the study conducted by Dhungana et al., (2017). It may be for the reason that most of local people prefer goat rearing (3.2 goats per $\mathrm{HH}$ ) in the study area. The study conducted by Miller et al., (2015) found that goats were killed closer to fields and villages. Most of the local people have ordinary livestock corrals and graze them in their fallow agricultural fields, and thus this could be also another responsible factor for frequent livestock depredation. Most of the livestock sheds for corralling at nighttime were unusually open; only a few people have put their livestock (goats and pigs) in predation proof corrals. Furthermore, decrease of natural prey species in the national park and buffer zone forests may be forcing the tigers to kill livestock (Kolowski and Holekamp, 2006; Gusset et al., 2009). Our data do not enable us to discern whether these risk distributions are shaped more by carnivores or by livestock and people; so, we suggest future studies to directly pursue the reasons behind depredation.

Grazing inside the buffer zone forests and park is prohibited (GON, 1973) and so local people living in high-risk areas could consider implementing additional mitigation techniques such as traditional fence with white cloth, mesh wire solar fence, predator-proof enclosures and livelihood diversifications at community level to further reduce attacks of carnivores (Shivik, 2006) due to the increasing trend of livestock depredation since 2014 (Fig. 3). A study conducted by Lamichhane et al., (2018) in CNP showed that implementing conflict mitigation measures (solar fence, concrete/mess wire fences), community awareness program, and reduction on forest dependency along with livelihood diversification (increased off-farm household income and reduced grazing on forests) have essentially helped lessen the damage from wildlife including tigers. Similarly, previous research in Central India (Karanth et al., 2013) and in east Africa (Kolowski and Holekamp, 2006) also found that fencing was especially useful in mitigating attacks. 


\section{Conclusion}

This study revealed that the rate of livestock depredation in the Madi valley has been increasing for the last five years with goats and buffalo as the most depredated livestock, but in the rate of human attacks has decreased. The restoration of buffer zone forests in recent years had dwindled the physical distance between human beings, livestock and the tigers, which in turn has augmented the HTC cases. However, the trend of human fatalities has decreased as a result of less humanwildlife interactions due to reduction in forest resources dependency and other livelihood diversification options, for example, fish and poultry farming practiced by local communities in the recent years. Further, other activities and practices including the promotion of stall feeding by discouraging free grazing in forests and improvement of livestock corrals could minimize livestock depredation by tiger. In addition, to minimize the conflict, local communities have adopted some mitigation measures like using predation proof livestock shed for night -time corralling, change in livestock management system from open grazing to stall feeding, mesh wire solar fencing, fence using white cloths and livelihood diversifications. However, effective HTC resolution needs further investment on implementing some mitigation measures that are compatible to local people from CNP, BZUC and other conservation partners to support tiger conservation initiatives in the study area. Therefore, we recommend further detailed research on the effectiveness of local preventive and mitigation measures adopted by local communities to minimize HTC.

\section{Acknowledgements}

We gratefully acknowledge the financial assistance provided by the Hariyo Ban Program, WWF Nepal and Rufford Small Grants Foundation, (UK). We thank the Department of National Parks and Wildlife Conservation and Chitwan National Park for granting permission to carry out this research. We are grateful to the anonymous reviewers and editors for their valuable comments and suggestions to improve the quality of this paper. We would like to acknowledge all the helping hands during the field data collection and we are grateful to Assistant Conservation Officers - Mr. Ramesh Kumar Yadav and Mr. Shanta Bahadur Magar and entire Chitwan National Park family for field level coordination and necessary support.

\section{Conflict of Interest}

The authors declare no conflict of interest.

\section{References}

Ahearn, S. C., Smith, J. L. D., Joshi, A. R., \& Ding, J. 2001. TIGMOD: an individual-based spatially explicit model for simulating tiger/human interaction in multiple use forests. Ecological Modelling, 140(1-2): 81-97. http://dx.doi.org/10.1016/s03043800(01)00258-7.

Bagchi, S., \& Mishra, C. 2006. Living with large carnivores: predation on livestock by the snow leopard (Uncia uncia). Journal of 
Zoology, 268(3): 217-224. http://dx.doi. org/10.1111/j.1469-7998.2005.00030.x.

Bhatta, S. R., Karki, J. B. \& Paudel, B. S. 2007. Situation of tiger-human conflict and action taken/required in Nepal. In Manandhar, L. P. (eds). Biodiversity conservation efforts in Nepal. GoN (DNPWC). PP 10-12.

Bhattarai, B. R. \& Fischer, K. 2014. Humantiger Panthera tigris conflict and its perception in Bardia National Park, Nepal. Fauna \& Flora International, Oryx, 48(4): 522-528. http://dx.doi. org/10.1017/S0030605313000483.

Budhathoki, P. 2012. Developing conservation governance strategies: holistic management of protected areas in Nepal. PhD thesis. University of Greenwich, London, UK.

Carter, N. H., Riley, S. J., Shortridge, A., Shrestha, B. K., \& Liu, J. 2013. Spatial Assessment of Attitudes toward Tigers in Nepal. AMBIO, 43(2): 125-137. http://dx.doi. org/10.1007/s13280-013-0421-7.

Chanchani, P., Lamichhane, B.R., Malla, S., Maurya, K., Bista, A., Warrier, R., \& Dhakal, M. 2014. Tigers of the Transboundary Terai Arc Landscape: Status, Distribution and Movement in the Terai of India and Nepal. National Tiger Conservation Authority, Government of India, and Department of National Park and Wildlife Conservation, Government of Nepal.

CNP (Chitwan National Park). 2019. Conflict incident records (fiscal year 2014/15 2018/19) archived at Chitwan National Park, Chitwan (accessed on March 20, 2019).

Dhungana, R., Savini, T., Karki, J.B., Dhakal, M., Lamichhane, B.R., \& Bumrungsri, S. 2017. Living with tigers Panthera tigris: patterns and correlates, and contexts of human- tiger conflict in Chitwan National Park, Nepal.

Dinerstein, E., Loucks, C., Heydlauff, A., Wikramanayake, E., Bryja, G., Forrest, J., Ginsberg, J., Klenzendorf, S., Leimgruber, P., \& O'Brien, T. 2006. Setting priorities for the conservation and recovery of wild tigers: 2005
2015. A user's guide. World Wildlife Fund, Wildlife Conservation Society, Smithsonian Institution, and National Fish and Wildlife Foundation. Save the Tiger Fund, Washington, DC.

Dinerstein, E., Loucks, C., Wikramanayake, E., Ginsberg, J., Sanderson, E., Seidensticker, J., Forrest, J., Bryja, G., Heydlauff, A., \& Klenzendorf, S. 2007. The fate of wild tigers. BioScience, 57: 508-514.

DNPWC \& DFSC. 2018. Status of Tigers and Prey in Nepal. Department of National Parks and Wildlife Conservation \& Department of Forests and Soil Conservation. Ministry of Forests and Environment, Kathmandu, Nepal.

FAO (Food and Agricultural Organisation), 2009. Human-wildlife conflict in Africa Causes, consequences and management strategies. Roma, FAO.

GON (Government of Nepal). 1973. The National Parks and Wildlife Conservation Act 1973 (fourth amendment in 1993), Kathmandu, Nepal.

GON (Government of Nepal). 2013. Wildlife Damage Relief Guideline 2013 (2nd Amendment 2017). Ministry of Forests and Soil Conservation, Kathmandu, Nepal.

Goodrich, J. M. 2010. Human-tiger conflict: A review and call for comprehensive plans. Integrative Zoology, 5(4): 300312. http://dx.doi.org/10.1111/j.17494877.2010.00218.x.

Goodrich, J.M., Lynam, A., Miquelle, D., Wibisono, H., Kawanishi, K., Pattanavibool, A. et al. 2015. Panthera tigris. In The IUCN Red List of Threatened Species 2015:e. T15955A50659951. http://dx.doi. org/10.2305/IUCN.UK.2015-2.RLTS. T15955A50659951.

Gubbi, S. 2012. Patterns and correlates of humanelephant conflict around a south Indian reserve. Biological Conservation, 148(1): $\quad$ 88-95. http://dx.doi. org/10.1016/j.biocon.2012.01.046.

Gurung, B. B. 2008. Ecological and sociological aspects of human-tiger conflicts in Chitwan National Park, Nepal. Ph. D. Thesis. University of Minnesota, USA. 
Gurung, B., Smith, J. L. D., McDougal, C., Karki, J. B., \& Barlow, A. 2008. Factors associated with human-killing tigers in Chitwan National Park, Nepal. Biological Conservation, 141(12): 3069-3078. http://dx.doi.org/10.1016/j. biocon.2008.09.013.

Gusset, M., Swarner, M. J., Mponwane, L., Keletile, K., \& McNutt, J. W. 2009. Human-wildlife conflict in northern Botswana: livestock predation by Endangered African wild dog Lycaon pictus and other carnivores. Oryx, 43(01): 67-72. http://dx.doi. org/10.1017/s0030605308990475.

Jackson, R., 1999. Snow leopards, local people and livestock losses. Cat News, 31: 22 - 23.

Joshi, A. R., Dinerstein, E., Wikramanayake, E., Anderson, M. L., Olson, D., Jones, B. S., a Hahn, N. R. 2016. Tracking changes and preventing loss in critical tiger habitat. Science Advances, 2(4): e1501675-e1501675. http://dx.doi. org/10.1126/sciadv.1501675.

Joshi, G., Neupane, B., Dahal, D., Shrestha, S., Dhakal, P., Jandug, C.M.B., and Gautam, D. 2020. Assessment of human wildlife conflict in Kailali district of Nepal. Journal of Animal Diversity (JAD), 2 (3): (article in press).

Karanth, K. U. \& Gopal, R. 2005. An ecologybased policy framework for humantiger coexistence in India. People and Wildlife: Conflict or Co-Existence? T. S. Woodruffe R, Rabinowitz A. Cambridge, Cambridge University Press: pp 373387.

Karanth, K. U., Nichols, J. D., Kumar, N. S., \& Hines, J. E. 2006. Assessing Tiger Population Dynamics Using Photographic Capture-Recapture Sampling. Ecology, 87(11): 2925-2937. Karanth, K.K., Kudalkar, S., 2017. History, location, and species matter: insights for humanwildlife conflict mitigation from India. Hum. Dimens. Wildl., 22 (4): 331-346. https://doi.org/10.1080/10871209.2017 .1334106 .

Karanth, K.K., Naughton-Treves, L., DeFries, R.S., \& Gopalaswamy, A.M. 2013. Living with wildlife and mitigating conflicts around three Indian protected areas. Environ
Manag 52: 1320-1332. http://dx.doi. org/10.1007/s00267-013-0162-1.

Karki, J.B., Pandav, B., Jnawali, S.R., Shrestha, R., Pradhan, N.M.B., Lamichhane, B.R., \& Jhala, Y.V. 2015. Estimating the abundance of Nepal's largest population of tigers Panthera tigris. Oryx, 49 (01): 150-156. https://doi. org/10.1017/S0030605313000471.

Kolowski, J., \& Holekamp, K.E.K. 2006. Spatial, temporal, and physical characteristics of livestock depredations by large carnivores along a Kenyan reserve border. Biological Conservation, 128: 529-541. http://dx.doi.org/10.1016/j. biocon.2005.10.021.

Lamichhane, B.R., Persoon, G.A., Leirs, H., Musters, C.J.M., Subedi, N., Gairhe, K.P., Pokheral, C.P., Poudel, S., Mishra, R., Dhakal, M., Smith, J.L.D., \& de Longh, H.H. 2017. Are conflict-causing tigers different? Another perspective for understanding human-tiger conflict in Chitwan National Park, Nepal. Global Ecology and Conservation, 11: 177-187. http://doi.org/10.1016/j. gecco.2017.06.003.

Lamichhane, B.R., Persoon, G.A., Leirs, H., Poudel, S., Subedi, N., Pokheral, C.P., Bhattarai, S., Thapaliya, B.P., \& de longh, H.H. 2018. Spatio-temporal patterns of attacks on human and economic losses from wildlife in Chitwan National Park, Nepal. PLoS ONE, 13(4): e0195373. https://doi.org/10.1371/journal. pone.0195373.

Löe, J., \& Röskaft, E. 2004. Large Carnivores and Human Safety: A Review. AMBIO: A Journal of the Human Environment, 33(6): 283-288. https://doi. org/10.1579/0044-7447-33.6.283.

Madhusudan, M. D. 2003. Living Amidst Large Wildlife: Livestock and Crop Depredation by Large Mammals in the Interior Villages of Bhadra Tiger Reserve, South India. Environmental Management, $\quad 31(4): \quad 466-475$. https://doi.org/10.1007/s00267-0022790-8.

Majupuria, T.C., Majupuria, R.K. 1998. Wildlife, National Parks and Reserves of Nepal: 
Resources and Management. Tec Press Books, Bangkok.

McDougal, C. 1987. The man-eating tiger in geographical and historical perspective. In R. L. Tilson, and U. S. Seal (Eds.). Tigers of the world: the biology, biopolitics, management, and conservation of an endangered species. Noyes Publications, Park Ridge, New Jersey, $p p$ 435-446.

Miller, J. R. B., Jhala, Y. V., \& Jena, J. 2015. Livestock losses and hotspots of attack from tigers and leopards in Kanha Tiger Reserve, Central India. Regional Environmental Change, 16(S1): https://doi.org/17-29. 10.1007/s10113-015-0871-5.

Mishra, C., Allen, P., Mc Carthy, T., Madhusudan, M.D., Bayarjargal, A. \& Prins, H.H.T. 2003 The role of incentive programs in conserving the snow leopard. Conservation Biology, 17: 1512-1520.

MM (Madi Municipality). 2017. Municipal Profile of Madi Municipality. Madi Municipality, Government of Nepal (accessed on January 15, 2019).

Muhammed, N., Kamal, M.T., Haque, F., Chowdhury, M.S.H. \& Koike, M. 2007. A study on the Royal Bengal Tiger (Panthera tigris tigris) of the Sundarbans in Bangladesh with special reference to tiger-human conflict. Journal of Social Research and Development, 4: 86-91.

Nyhus, P. J., \& Tilson, R. 2004. Characterizing human-tiger conflict in Sumatra, Indonesia: implications for conservation. Oryx, 38(1): 68-74. https://doi. org/10.1017/s0030605304000110.

Ogra, M. \& Badola, R. 2008. Compensating humanwildlife conflict in protected area communities: ground-level perspectives from Uttarakhanda, India. Hum Ecol., 36: 717-729.

Polisar, J., Maxit, I., Scognamillo, D., Farrell, L., Sunquist, M. E., \& Eisenberg, J. F. 2003. Jaguars, pumas, their prey base, and cattle ranching: ecological interpretations of a management problem. Biological Conservation, 109(2): 297-310. https://doi. org/10.1016/s0006-3207(02)00157-x.

Punch, K. F. 2006. Introduction to social research: quantitative and qualitative approaches. Sage publications. London, Thousand Oaks and New Delhi.

Sanderson, E., Forrest, j., Loucks, C., Ginsberg, J. Dinerstein, E., Seidensticker, J., Leimgruber, P., Songer, M., Heydlauff, A., O'Brien, T., Bryja, G., Klenzendorf, S., \& Wikramanayake, E. 2006. Setting priorities for the conservation and recovery of wild tigers: 2005-2015. The technical assessment. WCS, WWF, Smithsonian, and NFWF-STF, New York - Washington, D.C.

Sharma, U.R. 1991. Park-people interactions in Royal Chitwan National Park, Nepal. $P h D$ thesis. University of Arizona, Tucson, USA.

Shivik, J.A. 2006. Tools for the edge: what's new for conserving carnivores. Bioscience 56: 253-259.

Silwal, T., Kolejka, J., Bhatta, B. P., Rayamajhi, S., Sharma, R. P., \& Poudel, B. S. 2017. When, where and whom: assessing wildlife attacks on people in Chitwan National Park, Nepal. Oryx, 51(2): 370-377. https://doi. org/10.1017/s0030605315001489.

Silwal, T., Shrestha, B.P., Bhatta, B.P. \& Devkota, B.P. 2013. Revenue distribution pattern and park-people conflict in Chitwan National Park, Nepal. Banko Janakari, 23: 35-41.

Smith, J.L.D. 1993. The role of dispersal in structuring the Chitwan tiger population. Behaviour 124 (3): 165-195.

Thorn, M., Green, M., Dalerum, F., Bateman, P. W., \& Scott, D. M. 2012. What drives human-carnivore conflict in the North West Province of South Africa? Biological Conservation, 150(1): 23-32. https://doi.org/10.1016/j. biocon.2012.02.017.

Tilson, R. L. and Nyhus, P. J. 2010. Tigers of the world: the science, politics, and conservation of Panthera tigris. Amsterdam; Boston, Elsevier/Academic Press.

Van Bommel, L., Bij de Vaate, M. D., De Boer, W. F., \& De Iongh, H. H. 2007. Factors affecting livestock predation by lions in Cameroon. African Journal of Ecology, 45(4): 490-498. https://doi.org/10.1111/ 
j.1365-2028.2007.00759.x.

Wang, S. W., \& Macdonald, D. W. 2006. Livestock predation by carnivores in Jigme Singye Wangchuck National Park, Bhutan. Biological Conservation, 129(4): 558-565. https://doi.org/10.1016/j. biocon.2005.11.024.

Wegge, P., Yadav, S. K., \& Lamichhane, B. R. 2016. Are corridors good for tigers Panthera tigris but bad for people? An assessment of the Khata corridor in lowland Nepal. Oryx, 52(01): 35-45. http://dx.doi. org/10.1017/S0030605316000661.

Wikramanayake, E. D., Dinerstein, Robinson, E. J. G., Karanth, K. U., Rabinowitz, A., Olson, D., Mathew, T., Hedao, P., Conner, M., Hemley, G., \& Bolze, D. 1998. An ecology-based method for defining priorities for large mammal conservation: the tiger as case study. Conservation Biology, 12(4): 865-878. 